\title{
TRANSFORMASI KERTAMASA DALAM PRIVATISASI BADAN USAHA MILIK NEGARA
}

\author{
A. A. Gede D. H. Santosa \\ Fakultas Hukum Universitas Udayana Bali \\ E-mail : gianyarsantosa@yahoo.com
}

\begin{abstract}
ABSTRAK
Privatisasi BUMN menimbulkan kontroversi dan belum mampu mensejahterakan rakyat Indonesia. Tujuan dari penelitian ini adalah untuk mengetahui apakah Kertamasa sebagai kearifan lokal organisasi tradisional subak pada masyarakat Bali dapat ditranformasikan dalam privatisasi BUMN. dan untuk mengetahui bagaimakah perwujudannya.

Penelitian ini dilaksanakan dengan menggunakan metode holistik dengan menggunakan pendekatan intetralistik dan obyektif. Integralisisasi disini berupaya menyatu padukan antara nilai, norma hukum, fakta dan keterampilan. Obyektivikasi berupaya menjadikan ilmu hukum itu berguna bagi semua orang.

Hasil penelitian menunjukkan bahwa nilai-nilai Kertamasa yang dapat ditransformasi dalam privatisasi BUMN adalah nilai-nilai yang bersifat fundamental yang meliputi masa kreatif, kemajuan, kemakmuran, keunggulan, keamanan, ketertiban, harmonis seimbang antara lahir dan bhatin. Nilai nilai fundamental dari Kertamasa menjadi nilai dasar untuk penjabaran nilai-nilai intrsumen dan nilai praksis dalam privatisasi BUMN. Transformasi Kertamasa dalam privatisasi BUMN berwujud nilai instrumental dan nilai praksis yang bersumber pada nilai fundamental Kertamasa. Nilai instrumental dan nilai praksis belum tercermin dalam ketentuan privatisasi yang diatur dalam UU BUMN, untuk itu perlu dilakukan perubahan terhadap ketentuan privatisasi dalam UU BUMN.
\end{abstract}

\section{Kata Kunci : Tranformasi, Kertamasa, Privatisasi, BUMN.}

\section{ABSTRACT}

Privatization of SOEs fallouts controversies and yet is incapable of delivering welfares for Indonesian societies. This research aimed to find out whether Kertasama as local wisdom of Subak Traditional Organization within Balinese societies might be able to be transformed on privatization of SOEs, as well as its implementation.

This research conducted through a holistic method by using an integrality and objective approach. Integrality represented an attempt to combine among value, legal norm, fact and skill. Objectivity represented an attempt to make the legal science would be beneficial for the entire people.

The result of this research showed that the values of Kertasama that should be transformed on privatization of SOEs were about the fundamental values concealing the period of creativity, advancement, prosperity, superiority, security, orderliness, harmonize, as well as balance internally and externally. The fundamental values of Kertasama remained the basic value of the elaboration of instrumental values and practical values on privatization of SOEs. Kertasama transformation on privatization 
of SOEs represented instrumental values and practical values that obtained on the fundamental values of Kertasama. The instrumental values and practical values were not reflected yet on the provision of privatization as in accordance with the regulation within SOEs Law, therefore, an amendment on the provision of privatization within the SOEs Law were necessarily indispensable.

Key Word: Transformation, Kertasama, Privatization, SOEs

\section{Pendahuluan}

Dalam kurun waktu dua-tiga dasa warsa terakhir ini privatisasi Badan Usaha Milik Negara ( Selanjutnya disebut BUMN) menjadi salah satu isu publik yang menarik kalau tidak bisa disebut seksi. Hal itu bisa diketahui dari pengamatan kita bahwa isu ini menjadi head line pemberitaan media mainstream di Indonesia. Privatisasi BUMN juga menjadi tema dalam forum-forum diskusi oleh berbagai segmen dan strata masyarakat Indonesia.

Kebijakan privatisasi BUMN pertama kali terjadi pada masa pemerintahan Presiden Soeharto pada tahun 1991. Dalam kurun waktu 19911999 tercatat 9 ( sembilan) BUMN yang di privatisasi. PT Semen Gresik menjadi BUMN pertama terkena program privatisasi pada. Adapun BUMN lainnya yang masuk dalam daftar privatisasi diantaranya PT Aneka Tambang, PT Pupuk Kaltim, PT Kimia Farma. Sementara itu pada pada masa pemerintahan presiden Megawati Sukarno Putri terdapat 19 (sembilan belas) BUMN masuk dalam program privatisasi. Program privatisasi BUMN yang terealisasi dalam rentan tahun 2001-2004 antara lain, PT Indosat PT Telkom,PT BNI, PT Batu Bara Bukit Asam, PT BRI, PT Bank Mandiri (http://nusantaranews.wordpress.com /2009/06).

Privatisasi Indosat yang dibeli oleh Perusahaan BUMN Singapura Temasek adalah privatisasi BUMN yang banyak mendapatkan sorotan publik. Salah satu tujuan dari privatisasi adalah dalam rangka menutup defisit APBN yang disebabkan karena krisis ekonomi yang dialami Indonsia tahun 19981999 dan sekaligus merupakan salah satu persyaratan untuk paket bantuan keuangan yang diberikan International Monetery Fund ( IMF ) dan World Bank ( WB ) untuk Indonesia dalam mengatasi krisis ekonomi. Kontroversi muncul karena persyaratan yang ditetapkan IMF dan WB untuk memprivatisasi BUMN dianggap sebagai titipan yang hendak mengarahkan perekonomian Indonesia menuju faham kapitalis liberal. Alasan lainya dari mereka yang tidak setuju dengan privatiasi adalah karena Indosat merupakan salah satu aset negara yang mempunyai nilai ekonomis. Indonesia akan mengalami kerugian secara ekonomi atas peralihan kepemilikan Indosat ke tangan asing. Indosat dipandang mempunyai nilai strategis dalam bidang pertahanan dan keamanan negara karena bergerak dibidang yang komunikasi. Dengan dikuasainya Indosat oleh asing dalam hal ini Temasek Singapura dikhawatirkan pemerintah Singapura mengontrol dan mengetahui sistem pertahanan dan keamanan serta rahasia negara (http://jakarta45.wordpress.com). 
Privatisasi Indosat ini kemudian menjadi isu politik karena berdekatan dengan tahun pemilu yaitu pemilu legislative dan presiden 2004, berbagai spekulasipun muncul sebagai isu dalam kampanye untuk saling menjatuhkan dan mengalahkan satu sama lain.

Pada masa pemerintahan Presiden Susilo Bambang Yudhoyono ( SBY), kebijakan privatisasi BUMN terus berlanjut. Tahun 2008 pemerintah mengumumkan akan memprivatisasi 44 ( empat puluh empat) BUMN. Pada tahun 2009 program privatisasi telah dilakukan terhadap 30 ( tiga puluh) BUMN (http://liputanislam.com). Dari sejumlah privatisasi BUMN yang terealisasi dalam masa pemerintahan Presiden SBY, Privatisasi Karakatau Steel menjadi privatisasi BUMN yang menuai kontroversi. Kontroversi muncul berkenaan dengan harga saham Karakatau Steel yang ditetapkan sebesar Rp 850 per lembar saham, ternyata jauh dibawah harga pasar yang mencapai Rp 1200-an per saham. Sehingga muncul berbagai spekulasi tentang ketidakberesan dibalik privatisasi Karakatau Steel yang ujungnya merugikan negara (http://sunarsip.com).

Dengan menelusuri perjalanan kebijakan privatisasi BUMN dari pemerintahan Presiden Soeharto, Presiden Megawati dan Presiden SBY dapat ditemukan beberapa aspek yang mewarnai kontoversi kebijakan privatiasi BUMN yaitu aspek ideologi, aspek ekonomi, aspek hukum.

Privatisasi BUMN mengandung aspek ideologi artinya privatisai adalah persoalan ideologi. Dalam privatisasi ada ideologi yang saling berhadapan yaitu privatisasi yang berbasis Ideologi kapitalis liberal disatu sisi dihadapkan dengan nasionalis yang berbasis Pancasila dan UUD 1945. Aspek ideologi ini kemudian menjadi asal muasal perdebatan pada aspek aspek lainnya.

Dari aspek ekonomi, pada akhirnya semua diskusi dan kontroversi mengenai aspek ekonomi privatisasi BUMN berujung pada pertanyaan apakah privatisasi menguntungkan secara ekonomi dan mensejahtrakan rakyat. Privatisasi BUMN berkaitan dengan perekonomian nasional. BUMN menjadi salah satu penggerak perekonomian nasional karena dari segi jumlah yang tidak sedikit dan berbagai jenis usaha dari hulu hingga hilir. Sebagai penggerak perekonomian nasional BUMN menjadi satu instrument negara untuk mensejahtrakan masyarakat. BUMN memberikan kontribusi terhadap Anggaran Pendapatan dan Belanja Negara (APBN ) melalui pajak dan deviden. Sebagaimana diketahui salah satu alasan privatisasi BUMN adalah sebagai salah satu sumber pendanaan bagi APBN sebagai sumber pembiayaan pembangunan.

Sebagai konsekuensi dari perdebatan dalam aspek ideologi, kontroversi dalam aspek hukum berkisar pada landasan hukum dalam kebijakan privatisasi BUMN dengan munculnya ketentuan mengenai privatisasi BUMN dalam Undang-Undang No 19 tahun 2003 tentang BUMN ( UU BUMN ). Sebelum keluarnya UU BUMN kebijakan Privatisasi BUMN sepenuhnya didasarkan pada produk-produk hukum yang 
dikeluarkan oleh eksekutif/ presiden dan melalui kementrian terkait. Pengaturan tentang privatisasi BUMN dalam UU BUMN diatur dalam pasal 74 sampai pasal 84. Produk turunan dari UUBUMN ini adalah Peraturan Pemerintah No 33 Tahun 2005 dan PP No 33 Tahun 2009 yang mengatur tentang tata cara privatisasi Persero,selanjutnya ada Kepres No 18 Tahun 2006 mengenai pembentukan komite privatisasi Persero,dan Peraturan Menteri BUMN No PER01/MBU/2010 mengenai cara privatisasi, penyusunan program tahunan privatiasi dan penunjukan lembaga dan/ atau profesi penunjang serta profesi lainnya. Ekonom INDEF Drajad Wibowo berpendapat bahwa UUBUMN semakin memperlonggar rambu-rambu privatisasi karena dianggap memberikan kewenangan yang besar kepada Kementrian BUMN untuk melakukan privatisasi sementara pengawasan terhadap pelaksanaan privatisasi tidak jelas (http://hukumonline.com).

Berbagai kontroversi dalam aspek ideologi, ekonomi dan hukum dalam kebijakan privatisasi BUMN sebagaimana yang telah diuraikan di atas menunjukan suatu kecendrungan ketidakteraturan, dan ketidaktertiban. Pada sisi yang lainnya Privatisasi BUMN yang diharapkan mampu mendorong pelaksanaan dan perwujudan demokrasi ekonomi sebagai upaya peningkatan rakyat pada kenyataan dipandang belum berdampak pada kesejahtraan rakyat, seperti disampaikan oleh mantan Menteri Negara BUMN 2004-2007 Sugiarto dalam seminar dan bedah buku kebijakan privatisasi BUMN: Apresiasi untuk Almarhum Prof.Dr
Mas'ud Machfoed, M.B.A., Ak, yang digelar di Magister Sains dan Doktor Fakultas Ekonomika dan Bisnis UGM 1 Januari 2010. Selanjutnya dikatakan Sugiarto dorongan privatiasi BUMN di Indonesia lebih mengedepankan kebutuhan untuk memenuhi defisit APBN. Indikasi dari Privatisasi BUMN yang belum berdampak pada kesejahtraan rakyat adalah terdapatnya kenaikan tingkat angka pengangguran setelah adanya privatisasi (http://www.ugm.ac.id).

Dengan memperhatikan perjalanan kebijakan privatisasi BUMN dengan berbagai macam kontroversi dan dampaknya yang belum optimal pada kesejahtraan rakyat, maka perlu untuk melakukan kajian dan evaluasi terhadap kebijakan privatisasi BUMN. Pertanyaan -pertanyaan yang dapat diajukan dalam rangka kajian dan evaluasi privatisasi BUMN ini diantaranya apakah ada yang salah dengan privatisasi, mengapa privatisasi memunculkan kontroversi, mengapa privatisasi belum berdampak pada kesejahtraan rakyat dan seterusnya. Jawaban atas pertanyaan itu bertujuan untuk memberikan referensi bagi kelanjutan kebijakan privatisasi BUMN dan dalam kontek inilah tulisan ini dibuat.

Tulisan ini mengangkat sebuah konsep yang kemudian dikaitkan dengan privatisasi BUMN yaitu Kertamasa. Konsep Kertamasa adalah salah satu kearifan lokal yang meramu keharmonisan yang pada zaman dulu dijadikan salah 
satu pilar kesejahtraan di Bali. Makna Kertamasa adalah keteraturan, ketertiban dan kehematan sumberdaya. Kertamasa merupakan tradisi dari organisasi tradisional bidang pertanian yang dikenal dengan sebutan subak. Tradisi ini adalah pola bertani yang mengedepankan pola pembagian pola pembagian musim secara secara periodik ,teratur dan tertib yaitu musim padi, musim palawija, musim gadon dalam suatu kawasan Subak.

Penulis mengangkat konsep Kertamasa dikaitkan dengan privatisasi BUMN, karena pada dasarnya dorongan Privatisasi BUMN adalah bertujuan untuk kesejahtraan masyarakat. sama dengan tujuan dari konsep Kertamasa walaupun konsep privatisasi BUMN bersumber dari ideologi barat liberal kapitalis sedangkan konsep Kertamasa merupakan kearifan lokal berupa nilai nilai yang bersumber dan masyarakat Indonesia. Berdasarkan atas kesamaan tujuan namun berasal dari sumber yang berbeda maka menarik untuk mengkaji apakah nilai-nilai yang ada dalam konsep Kertamasa dapat di transformasi kedalam privatisasi BUMN dan kalau kemudian nilai nilai dalam konsep Kertamasa dapat ditransformasi kedalam privatisasi BUMN bagaimanakah perwujudannya. Jawaban atas pertanyaan tersebut diharapkan menjadi salah satu referensi sehingga tidak ada lagi kontroversi dalam privatisasi BUMN, kemudian yang tercipta keteraturan, ketertiban, keharmonisan dan kesejahtraan masyarakat sebagaimana tujuan dari privatisasi BUMN, untuk itu tulisan ini diberi judul" Transformasi Kertamasa dalam Privatisasi BUMN". Berdasarkan uraian latar belakang yang telah diuraikan di atas, permasalahan yang diangkat dalam tulisan ini adalah :

1. Apakah Kertamasa dapat di transformasi dalam privatisasi BUMN?

2. Bagaimanakah perwujudan dari transformasi Kertamasa dalam privatisasi BUMN?

\section{Pembahasan \\ Pengertian Privatisasi BUMN}

Dalam Pasal 1 angka 12 UU BUMN, Privatisasi adalah penjualan saham Persero, baik sebagian maupun seluruhnya kepada pihak lain dalam rangka meningkatkan kinerja dan nilai perusahaan, memperbesar manfaat bagi negara dan masyarakat, serta memperluas pemilikan saham oleh masyarakat. Sementera itu Persero adalah salah satu bentuk dari BUMN selain Perusahan Umum. menurut pasal 1 angka 2 Persero adalah BUMN yang berbentuk perseroan terbatas yang seluruh atau paling sedikit 51\% ( lima puluh satu persen ) sahamnya dimiliki oleh Negara Republik Indonesia yang tujuan utamnya mengejar keuntungan. Dengan demikian menurut UU BUMN privatisasi hanya bisa dilakukan terhadap BUMN yang berbentuk Persero.

Sementara itu pengertian privatisasi menurut Tisa Belasuriya " privatization is a transfer, wholly or in part, permanently or on aa temporary lease, of the ownwership and or management of state owned enterprise to the private sector, (Belasuriya,1993) artinya privatisasi BUMN merupakan suatu 
proses peralihan baik secara keseluruhan atau sebagian kepemilikan BUMN secara tetap atau sementara kepada sector swasta.

Aminudin Ilmar menyatakan bahwa privatisasi BUMN adalah suatu proses kegiatan pengalihan kepemilikan saham yang dahulunya dikuasai oleh negara dalam BUMN kemudian diserahkan kepada swasta untuk menguasai dan menyelengarakannya. Dalam privatisasi BUMN harus tercermin adanya suatu proses peralihan penguasaan dari negara kepada swasta yakni minimal jumlah saham yang harus dilepaskan adalah $51 \%$ dari jumlah saham milik negara dalam BUMN. Penetapan batas minimal berapa jumlah saham milik negara dalam BUMN yang dilepaskan atau dialihkan yaitu minimal $51 \%$ merupakan suatu keharusan karena berkaitan dengan penguasaan dan penyelenggaraan dari BUMN yang dahulunya di kuasai dan diselengarakan oleh negara secara monopolistic (Ilmar, 2012).

Menurut penulis pengertian privatisasi BUMN dari Aminudin Ilmar di atas memiliki penekanan pada peralihan penguasaan dan penyelenggaraan BUMN dari negara kepada pihak swasta sehingga batas minimal saham milik negara yang ada di BUMN dialihkan minimal $51 \%$. Berkaitan dengan penekanan peralihan penguasaan dan penyelenggaraan BUMN dari negara kepada Pihak Swasta , rumusan ketentuan minimal $51 \%$ saham yang dialihkan adalah benar jika s $100 \%$ saham yang ada di BUMN sebelum dialihkan seluruhnya milik negara. Tetapi apabila kita menggunakan rumusan pengertian BUMN Persero yang terdapat dalam UU BUMN yang menyatakan untuk dapat dikualifikasikan sebagai BUMN Persero kepemilikan negara bisa seluruhnya atau paling sedikit 51\% maka apa yang dirumuskan minimal 51\% dialihkan kepada pihak swasta untuk bisa menguasi dan menyelenggarakan BUMN menjadi kurang tepat. Dalam hal kepemilikan negara atas saham dalam BUMN sebelum privatisasi $51 \%$ ( sesuai rumusan pengertian BUMN dalam UU BUMN) maka pengalihan dibawah 51\% kepada pihak swasta sudah cukup untuk membuat pengusaan dan penyelenggaran beralih dari negara kepada pihak swasta. Menurut penulis rumusan yang lebih tepat adalah dalam privatisai peralihan kepemilikan saham BUMN dari negara kepada pihak swasta mengakibatkan kepemilikan negara atas saham perusahaan kurang dari $50 \%$ atau kepemilikan negara maksimal $49 \%$ atas seluruh saham perusahaan. Dengan demikian penguasaan dan pengendalian beralih dari negara kepada swasta.

Sebelum keluarnya UU BUMN, dalam sejarahnya setelah Indonesia merdeka BUMN / Perusahaan Negara diatur dalam Peraturan Pengganti Undang-undang ( UUPrp ) No 19 Tahun 1960. UU ini menjadi induk dari Perusahan-Perusahan Negara yang sudah ada pada zaman belanda yang diatur berdasarkan Indonesische Comptabilteitswet ( Staatblad 1925 N0.448) dan Indonesische Bedrijvenwet ( Staatblad 1927 N0 419). Menurut UU ini pada prinsipnya hanya dikenal satu macam perusahaan Negara padahal perusahan perusahan negara tersebut 
mempunyai latar belakang dan bidang tugas yang berbeda-beda. Kemudian keluar Instruksi Presiden Nomor 17 Tahun 1967 yang menginstruksikan kepada semua Mentri dan pimpinan lembaga pemerintah lainnya yang membawahi Perusahaan Negara dalam segala bentuknya serta semua pimpinan bentuk-bentuk usaha negara yang berdiri sendiri, untuk mengadakan persiapan penertiban/penyempurnaan/ penyederhanaan dalam rangka menunggu keluarnya UU baru yang mengatur Perusahaan Negara. kemudian lahirlah UU yang dimaksud yaitu UU NO 9 tahun 1969. Menurut UU ini perusahaan negara terdiri dari tiga macam yaitu Perusahaan Negara Jawatan ( Perjan , Perusahaan Negara Umum ( Perum ) dan Perusahaan Negara Perseroan ( Persero ). Disamping itu ada badan usaha negara yang karena fungsi dan sifatnya dianggap khusus diatur secara tersendiri misalnya Pertamina diatur dalam UU No 8 Tahun 1967, BNI 46 diatur dalam UU No 17 Tahun 1968, BDN diatur dalam UUNo 18 Tahun 1968, BBD diatur dalam UU No 19 Tahun 1968, BRI diatur dalam UU No 21 Tahun 1968 ), Bank Exim diatur dalam UU No 22 Tahun 1968. Setelah terbit Undang-undang No 7 Tahun 1992 tentang Perbankan bank-bank negara ini dikonversi menjadi Persero dengan Peraturan Pemerintah masing-masing (Rudy Prasetya, 2001).

\section{Privatisasi BUMN dan Konsep Leberalisme}

Privatisasi BUMN pertama kali terjadi pada masa pemerintahan Presiden Soeharto pada tahun 1991. PT Semen Gresik menjadi BUMN pertama terkena program privatisasi. Program privatisasi BUMN ini didasarkan pada Instruksi Presiden Nomor 5 Tahun 1989 dan yang menginstruksikan kepada mentri teknis untuk melakukan penyelamatan dan penyempurnaan pengelolaan BUMN dan Peraturan Pemerintah Nomor 55 Tahun 1990 tentang Perusahaan Persero yang menjual sahamnya kepada masyarakat melalui pasar modal. Sejak keluarnya Instruksi Presiden dan Peraturan pemerintah tersebut salah satu cara dalam upaya pembenahan BUMN khususnya untuk menyehatkan pengelolaan dan penyelenggaraan BUMN maka era privatisasi BUMN di Indonesia telah dimulai.

Privatisasi BUMN di Indonesia dianggap sebagai salah satu alternatif pembanahan dan penyehatan BUMN melalui pengalihan sebagian atau keseluruhan saham BUMN maupun kontrol kepada pihak swasta. Selain itu Privatisasi BUMN dimaksudkan pula sebagai salah satu sarana pemerataan pendapatan melalui kegiatan pemilikan saham oleh masyarakat, disamping sebagai sarana penarikan dana masyarakat secara cepat guna pembayaran utang luar negeri Indonesia. Privatisasi BUMN diyakini dapat memperbaiki struktur modal BUMN yang sudah dirasakan sebagai beban bagi megara dan sekaligus meningkatkan kemampuan pengelolaan BUMN dalam hal efisiensi, efektifitas maupun produktivitasnya sehingga akan terjadi sinergi antara efisiensi,kompetensi dan laba. 
Dalam buku Popular Capitalism dari John Redwood disebutkan Konsep privatisasi muncul berhubungan dengan lahirnya konsep pemikiran bahwa aktifitas ekonomi dan bisnis akan lebih baik bilamana diserahkan kembali kepada swasta, oleh karena usaha yang dikelola swasta umumnya lebih baik dan lebih efisien dan produktif. Dengan diserahkannya BUMN kepada pihak swasta, maka negara dapat lebih mengonsentrasikan diri dan dananya bagi kegiatan-kegiatan pelayanan umum masyarakat (John, 1989). Pemikiran ini lazimnya dikenal sebagai konsep liberalisme.

Liberalisme atau untuk konteks saat ini lebih tepat di sebut neoliberalisme menurut Herley sebagaimana dikutip Bagong Suyanto adalah suatu teori ekonomi politik yang menyatakan bahwa kesejahtraan manusia paling memungkinkan dicapai dengan cara meliberalisasikan kebebasan dan keterampilan entrepreneurial individu dan menempatkan kebebasan dan keterampilan itu ke dalam suatu kerangka pranata yang dicirikan oleh hak milik pribadi yang kuat, pasar bebas dan perdagangan bebas (Redwood, 1989). Liberalisme merupakan landasan atau dasar berkembangnya kapitalisme. Kapitalisme adalah suatu paham yang meyakini bahwa pemilik modal bisa melakukan usahanya untuk meraih keuntungan sebesar-besarnya. Demi prinsip tersebut, maka pemerintah tidak dapat melakukan intervensi pasar demi keuntungan bersama. Kapitalisme sebagaimana diyakini Adam Smith telah terbukti mendorong produktifitas. Ekonomi pasar bebas diyakini memberikan manfaat yang positif, terutama jika negara tidak menghalangi dengan batasan batasan. Di dalam sistem kapitalisme, prinsip yang berlaku dan dikembangkan laissez fair ( biarkan bertindak sendiri ) , namun menurut Smith ini semua justru akan membuat kapitalisme berkembang menguntungkan masyarakat karena dikendalikan oleh invicible hand ( tangan yang tidak terlihat ) yang secara alamiah akan mengatur keseimbangan antara kebebasan dan kebutuhan (hukum permintaan dan penawaran) (John, 1989).

Elizabeth Martinez dan Arnold Garcia memberikan memberikan poin poin pokok mengenai pengertian neoliberalisme yaitu;

1. Peraturan pasar-kebebasan bagi modal, barang dan jasa, dimana pasar memiliki mekanismenya sendiri yang membiarkan trickle-down effect dalam distribusi kesejahtraan. Neoliberalisme juga mencakup pembubaran organisasi organisasi buruh dan penghilangan rintangan atau hambatan bagi mobalitas modal, seperti peraturan-peraturan, semisal pajak. Kebebasan itu sendiri berasal dari negara atau pemerintah.

2. Pengurangan pengeluaran publik uakan ntuk segala jaminan social, seperti kesehatan hingga pendidikan dari pemerintah.

3. Deregulasi untuk membolehkan kekuatan pasar bisa bereaksi sebagai sebuah mekanisme 
pengaturan dirinya ( self regulation mechanism )

4. Privatisasi perusahaan perusahaan negara.

5. Mengubah persepsi publik dari kolektivisme menjadi individualisme (Winarno, 2013).

Dalam kaitannya antara hukum dengan Liberisme ini relevan untuk mengutip pendapat dari Satjipto Rahardjo yang mendukung pendapat dari Max Weber bahwa pertumbuhan sistem hukum modern tidak dapat dilepaskan dari kemunculan industrialisasi yang kapitalis. Sistem hukum menjadi seperti sekarang karena tuntutan industrialisasi yang kapitalis adanya suatu suatu tatanan normatif yang mampu mendukung pola kerja rasional. Dengan demikiam hukum mengabdi dan melayani masyarakat industry-kapitalis (Satjipto Rahardjo,2003).

\section{Arti dan Makna Filosofi Kertamasa}

Istilah Kertamasa berasal dari bahasa sansekerta yang terbentuk dari kata Krta dan Masa. Krta dapat berarti makmur, berkembang maju, ulung sempurna. Masa berarti berarti bulan , musim, jam, waktu tertentu, waktu yang tepat. Dengan demikian Kertamasa dapat diartikan musi kemakmuran, masa kemajuan, zaman keemasan. Sebelum diserap kedalam bahasa bali istelah kertamasa terlebih dahulu diserap dalam bahsa jawa kuno. Kata krta ditemukan dalam berbagai teks jawa kuno anatara lain Slokantara , Kakawin Ramayana, Kakawin Hariwangsa, Kakawin Bharatayudhha, Kakawin Gatotkacasraya, Kakawin Sutasoma. Begitu pula ditemukan dalam sejumlah teks Jawa Kuno anatara lain
Adiparwa, Bhisma Parwa Agastya Parwa (Nyoman Suarka, 2014).

Dalam masyarakat Bali istilah Kertamasa dikenal dalam subak. Subak adalah suatu organisasi tradisional yang ada di Bali dan diwariskan secara turun temurun oleh masyarakat Bali didalamnya terkandung hal hal yang berhubungan dengan pengetahuan dan teknologi pengairan menyangkut pola tanam, peralatan, pertanian, irigasi dan aktivitas ritual.

Pada awalnya Kertamasa dimaknai musim bertani padi, atau bulan bulan yang tepat untuk menanam padi disawah.. Istilah kertamasa kemudian diparadokkan dengan istilah tulak sumur yakni masa menanam padi yang menyalahi musim. Dalam perkembangannya istilah kertamasa mengalami perubahan yaitu pola tanam padi secara bergilir antara padi dan palawija. Sementara tolak sumur adalah pola tanam padi secara terus menerus.tanpa diselingi palawija.

Dalam pelaksanaannya Kertamasa mengandung makna bahwa petani dilakangan subak bersepakat untuk bertanam bersama secara serentak. Kearifan ini ternyata bermanfaat untuk mengendalikan hama, dan membangun harmoni dan kebersamaan dikalangan anggota subak. Pada zaman dahulu pada saat patani masih menanam padi lokal hama yang sering menyerang tanaman adalah tikus dan walangsangit. Karena dilaksanakan sistem Kertamasa maka serangan hama pada tanaman padi akan terasa 
ringan karena sebaran serangan hama akan sangat luas yakni seluas kawasan subak yang bersangkutan. Di lain pihak eksistensi hama juga dapat dikendalikan karena tidak selalu tersedia makanan untuk dan tempat berlindung bagi hama.misalnya kalau ditanam secara bersamaan tanaman padi dan kemudian secara bersamaan menanam palawija maka hama yang terbiasa hidup pada tanaman padi tidak mendapat makanan tidak mendapatkan makanan dari tanaman palawija berikutnya. Kertamasa juga dapat mengembangkan sikap harmoni dan kebersamaan Kalau mereka bertanam secara bersamaan dan ada diantara mereka yang kekurangan air irigasi, maka mereka akan mengembangkan kebiasaan saling pinjam air irigasi (Windia, 2014).

Konsep Kertamasa yang terdapat dalam subak merupakan wujud dari kebudayaan Bali dalam interaksi manusia Bali pada kehidupan agraris dan telah menjadi kearifan lokal Bali yang dipakai masyarakat untuk mengekspresikan gagasan dinamika kehidupan masyarakat yang agraris dalam mengelola dan mengolah sumberdaya alam secara kreatif menurut hukum alam sesuai dengan ruang dan waktu dengan mengedepankan keteraturan, ketertiban, keharmonisan, keseimbangan alam sekala-niskala, keseimbangan antara lahir dan batin melewati segala jaman untuk meraih masa kehidupan yang aman damai dan sejahtra. Sementara di Jawa kearifan lokal yang mempunyai kemiripan dengan konsep Kertamasa ini diberi istilah Pranata Mangsa sedangkan di Sulawesi Selatan disebut dengan
Lontara (Faisal Efendi, Effendi Pasandaran dan Achmad M. Fagi, 2003).

\section{Kertamasa Dalam Kaitannya Dengan Pancasila.}

Sebagai suatu kearifan lokal yang bersumber dari kebudayaan bali khusunya Subak , dalam Kertamasa terkandung nilai-nilai yang memiliki makna dinamik sesuai ruang dan waktu, meliputi makna masa kreatif, masa kemajuan, masa kemakmuran dan masa keunggugulan dalam masa kehidupan yang aman tertib, harmonis, dan seimbang antara lahir dan bhatin. Dalam kaitannya Kertamasa sebagai nilai yang bersumber dan hidup dari masyarakat Kertamasa pada hakekatnya merupakan dari nilai nilai yang terkandung dalam Pancasila.

Nilai-Nilai yang terkandung dalam Pancasila merupakan sekumpulan nilai yang diangkat dari prinsip nilai yang hidup dan berkembang dalam masyarakat. Nilai nilai tersebut berupa nilai relegius, nilai adat istiadat kebudayaan (H.Kailan,2013). Pancasila sebagai sistem nilai telah mengakar dalam kehidupan bangsa Indonesia. Tertaman dalam tradisi, sikap perilaku, adat istiadat dan budaya bangsa. Pancasila tergolong nilai kerohaniahan yang di dalamnya terkandung nilai nilai lain secara lengkap dan harmonis, baik nilai material, nilai vital, nilai kebenaran dan kenyataan, nilai aesthetis, nilai ethis/moral maupun nilai relegius. Hal ini dapat terlihat pada susunan sila-sila Pancasila 
yang sistematis hierarkis, yang dimulai dari sila Pertama" Ketuhanan Yang Maha Esa "sampai dengan sila kelima" Keadilan sosial bagi seluruh rakyat Indonesia " (Sudjito,2012).

Nilai dalam derivasi atau penjabarannya dapat dikelompokan menjadi tiga macam yaitu nilai dasar, nilai instrumental, dan nilai praksis. Nilai dasar sebagai sumber norma yang pada gilirannya dapat direalisasikan dalam suatu kehidupan yang bersifat praksis. Aspek praksis tidak dapat bertentangan dengan nilai dasar yang merupakan sumber penjabaran norma dan realisasi praksis tersebut. Nilai Instrumental merupakan formulasi dari parameter yang merupakan suatu pedoman yang dapat diukur dan diarahkan. Nilai instrument ini merupakan suatu arahan, kebijakan atau strategis yang bersumberpada nilai dasar. Sementara nilai Praksis pada hakekatnya merupakan penjabaran lebih lanjut dari nilai instrumental dalam kehidupan yang nyata sehingga nilai praksis itu merupakan perwujudan dari instrumental. Dengan demikian nilai dasar, nilai instrumendan nilai praksis berhubungan secara koheren. Dalaim kaitannya dengan penjabaran dari nilai ini Pancasila adalah sumber dari segala sumber hukum. Nilai nilai Pancasila harus mewarnai secara dominan setiap produk hukum, baik dalam tataran pembentukan, pelaksanannya maupun penegakannya.

Pancasila sebagai dasar filsafat negara ditetapkan secara formal dalam Alinia IV Pembukaan UUD 1945 dengan demikian Pancasila memperoleh kedudukan sebagai norma dasar hukum positif. Konsekuensi dari dicantumnkanya Pancasila dalam pembukaan UUD 1945 adalah

1. Bahwa rumusan Pancasila sebagai Dasar Negara Republik Indonesia adaah seperti yang tercantum dalam Pembukaan UUD 1945 alinia 4.

2. Bahwa Pembukaan UUD 1945, berdasarkan pengertian ilmiah merupakan pokok kaedah negara yang fundemantal dan terhadap tertib hukum Indonesia mempunyai 2 macam kedudukan yaitu sebagai dasar dari tertib hukum dan sebagai tertib hukum tertinggi.

3. Bahwa Pembukaan UUD 1945 selain berkedudukan sebagai mukadimah juga berkedudukan sebagai sesuatu yang bereksistensi sendiri yang hakikatnya kedudukan hukumnya berbeda dengan pasal pasalnya. Karena pembukaan UUD 1945 adalah Pancasila maka tidak tergantung pada batang tubuhnya bahkan sumber dari batang tubuhnya.

4. Bahwa Pancasila dengan demikian mempunyai hakekat, sifat, kedudukan dan fungsi sebagai pokok kaedah negara yang fundamental yang menjelmakan diri sebagai dasar kelangsungan hidup Negara Republik Indonesia yang diproklamirkan tanggal 17 Agustus 1945.

5. Bahwa Pancasila sebagai inti dari Pembukaan UUD1945 mempunyai kedudukan yang kuat dan tidak dapat diubah dan terletak pada kelangsungan hidup Negara Republik Indonesia. 
Secara materiil pencantuman Pancasila dalam Alinia 4 Pembukaan UUD 1945 membawa konsekuensi tertib hukum Indonesia dijabarkan dari nilai-nilai yang terkandung dalam Pancasila. Sebagai sumber tertib hukum Indonesia Pancasila meliputi sumber nilai, sumber materi, sumber bentuk dan sifat (Sudjito,2012).

\section{Metode Penelitian}

Tulisan tentang Transformasi Kertamasa Dalam Privatisasi BUMN ini mengunakan metode penelitian holistik dengan menggunakan pendekatan intetralistik dan obyektif. Integralisisasi disini berupaya menyatu padukan antara nilai, norma hukum, fakta dan keterampilan. obyektivikasi berupaya menjadikan ilmu hukum itu berguna bagi semua orang (Sudjito, 2012). Dalam kaitan dengan tulisan ini Integralisasi terhadap nilai nilai yang terkandung dalam privatisasi BUMN yang berasal dari faham liberalisasi dan nilai Kertamasa yang merupakan kearifan lokal bali, ketentuan-ketentuan hukum tentang privatisasi BUMN termasuk UU BUMN dan fakta fakta mengenai privatisasi BUMN dan implikasinya untuk dianalisis secara keseluruhan dan sebagai suatu kesatuan yang utuh. Hasil dari pada analisis dengan pendekatan holistik ini diharapkan berguna bagi keberlanjutan privatisasi BUMN dengan tujuan untuk mencapai kesejahtraan bagi rakyat Indonesia.

\section{Transformasi Kertamasa Dalam Kebijakan Privatisasi BUMN.}

Wujud dari Kertamasa dalam pelaksanaannya oleh organisai tradisional Subak di Bali, adalah petani dikalangan subak bersepakat untuk bertanam bersama secara serentak ternyata bermanfaat untuk mengendalikan hama, dan membangun harmoni dan kebersamaan dikalangan anggota subak. pada saat petani menanam padi hama yang sering menyerang tanaman adalah tikus dan walangsangit. Karena dilaksanakan sistem Kertamasa maka serangan hama pada tanaman padi akan terasa ringan karena sebaran serangan hama akan sangat luas yakni seluas kawasan subak yang bersangkutan. Di lain pihak eksistensi hama juga dapat dikendalikan karena tidak selalu tersedia makanan untuk dan tempat berlindung bagi hama , misalnya kalau ditanam secara bersamaan tanaman padi dan kemudian secara bersamaan menanam palawija maka hama yang terbiasa hidup pada tanaman padi tidak mendapat makanan tidak mendapatkan makanan dari tanaman palawija berikutnya. Kertamasa juga dapat mengembangkan sikap harmoni dan kebersamaan Kalau mereka bertanam secara bersamaan dan ada diantara mereka yang kekurangan air irigasi, maka mereka akan mengembangkan kebiasaan saling pinjam air irigasi.

Nilai nilai Kertamasa dalam pelaksanaannya oleh subak sebagaimana diuaraikan merupakan perwujudan dari nilai nilai dasar Kertamasa. Nilai nilai dasar tersebut memiliki makna dinamik sesuai ruang dan waktu, meliputi makna masa kreatif, masa kemajuan, masa kemakmuran dan masa keunggugulan dalam masa kehidupan yang aman tertib, 
harmonis, dan seimbang antara lahir dan bhatin.

Sebelum membahas lebih lanjut mengenai transformasi Kertamasa dalam Privatisasi BUMN, sebagai suatu analogi Kertamasa menjadi tema perhelatan tahunan Pesta Kesenian Bali ke XXX VI Tahun 2014 yang dimaknai sebagai dinamika kehidupan masyarakat agraris menuju kesejahtraan semesta. Makna dinamika kehidupan masyarakat agraris menuju kesejahtraan semesta merupakan nilai Kertamasa sebagaimana nilai dasar Kertamasa dalam kaitannya dengan Subak. Penjabaran lebih lanjut dari nilai dasar Kertamasa yang terkandung dalam tema Pesta Kesenian Bali tersebut adalah penampilan para seniman dan sekehe sebisa mungkin mengunakan busana/ pakian yang tidak glamor,isian materi , gerak kreasi dan lagu sebisa mungkin membuat pementasan yang bisa digunakan di desa dengan dekorasi minimalis dan atribu yang menampilkan kemewahan ditiadakan dengan lebih mengutamakan bentuk garapan dan dan keindahan penampilan secara keseluruhan

(www.disbud.baliprov.go.id ). Dengan demikian berarti makna nilai dasar dari Kertamasa ditransformasikan kedalam Pesta Kesenian Bali sebagai tema bukan nilai dalam pelaksaan pelaksanaan penanaman serentak oleh para anggota subak sebagaimana sejarahnya pelaksanaan dari Kertamasa. Nilai-nilai pelaksanaan dari tema ini adalah ada dalam setiap pementasan seni dan kegiatan lainnya dalam perhelatan Pesta Kesenian Bali.

Dalam kaitannya dengan privatisasi BUMN pertanyaan adalah apakah Kertamasa dapat di transformasikan dalam privatisasi BUMN karena antara Kertamasa dengan privatisasi masing masing mempunyai sumber historis yang berbeda. Kertamasa bersumber dari tradisi yang tumbuh dan berkembang di dalam masyarakat Indonesia yaitu dalam organisasi Subak di Bali sementara itu privatisasi BUMN bersumber pada faham liberal dari negara-negara barat.

Sebagai suatu kearifan lokal Kertamasa pada hakekatnya merupakan nilai nilai yang menjadi yang tumbuh dan berkembang dalam tradisi masyarakat Indonesia yaitu organisasi Subak di Bali. Dalam kaitannya dengan Pancasila sebagai kristalisasi nilai nilai luhur yang dimiliki masyarakat Indonesia pada hakekatnya didalam Kertamasa terkdandung nilai nilai Pancasila.

Nilai dalam derivasi atau penjabarannya dapat dikelompokan menjadi tiga macam yaitu nilai dasar, nilai instrumental, dan nilai praksis. Nilai dasar sebagai sumber norma yang pada gilirannya dapat direalisasikan dalam suatu kehidupan yang bersifat praksis. Aspek praksis tidak dapat bertentangan dengan nilai dasar yang merupakan sumber penjabaran norma dan realisasi praksis tersebut. Nilai Instrumental merupakan formulasi dari parameter yang merupakan suatu pedoman yang dapat diukur dan diarahkan. Nilai instrumental ini merupakan suatu arahan, kebijakan atau strategis yang bersumberpada nilai dasar. Sementara nilai Praksis pada hakekatnya merupakan 
penjabaran lebih lanjut dari nilai instrumental dalam kehidupan yang nyata sehingga nilai praksis itu merupakan perwujudan dari instrumental. Dengan demikian nilai dasar, nilai instrumendan nilai praksis berhubungan secara koheren.

Dengan mengacu pada penjabaran nilai yaitu nilai fundamental, nilai istrumental dan nilai praksis dikaitkan dengan Kertamasa dalam subak dan Kertamasa sebagai tema dari Pesta Kesenian Bali yang telah penilis uraikan di atas maka dapat ditarik suatu benang merah bahwa Nilai Fundamental yang terdapat dalam Kertamasa subak adalah sama dengan nilai fundamental yang terdapat dalam Kertamasa sebagai tema Pesta Kesenian Bali. Sedangkan nilai instrumental dan nilai praksisnya adalah penjabaran lebih lanjut dari nilai fundamental kertamasa yang disesuaikan dengan konteksnyanya masing masing.

Penulis menggunakan analogi Kertamasa sebagai tema dalam Pesta Kesenian Bali dalam kaitannya dengan privatisasi BUMN adalah untuk tujuan bahwa Pesta atau festifal dalam hal ini pesta kesenian bersumber dari luar yang kemudian digunakan di Indonesia. Sama halnya dengan privatisasi yang bersumber faham liberal dari negaranegara barat. Walaupun bersumber dari barat bukan berarti Kertamasa yang merupakan nilai-nilai tradisional masyarakat Indonesai tidak dapat ditransformasi dalam privatisasi BUMN. Nilai nilai Kertamasa adalah nilai nilai yang bersifat fundamental yaitu nilainilai memiliki makna dinamik sesuai ruang dan waktu, meliputi makna masa kreatif, masa kemajuan, masa kemakmuran dan masa keunggugulan dalam masa kehidupan yang aman tertib, harmonis, dan seimbang antara lahir dan bhatin.

Nilai nilai Fundamental dari Kertamasa kalau kemudian di transformasi kedalam privatisasi BUMN menjadi nilai nilai dasar dan sumber sumber norma yang pada gilirannya dapat direalisasikan dalam kebijakan dan pelaksanaan privatisasi BUMN. Kebijakan atau strategis privatisai merupakan nilai instrumental sebagai formulasi dari parameter yang merupakan suatu pedoman yang dapat diukur dan diarahkan bersumberpada nilai dasar dalam hal ini nilai-nilai Fundamental Kertamasa. Sementara pelaksanaan dari privatiasi BUMN merupakan nilai praksis pada hakekatnya merupakan penjabaran lebih lanjut dari nilai instrumental sehingga nilai praksis itu merupakan perwujudan dari nilai instrumental privatisasi BUMN Dengan demikian nilai dasar, nilai instrumendan nilai praksis dalam privatisasi BUMN berhubungan secara koheren.

\section{Wujud Transformasi Kertamasa dalam Privatisasi BUMN}

Dengan dapat di transformasinya nilai fundamental dari Kertamasa dalam Privatisasi BUMN , maka pertanyaan berikutnya adalah bagaimanakah perwujudan dari nilai Kertamasa dalam privatisasi BUMN. Perwujudan nilai kertamasa dalam privatisasi BUMN ini merupakan nilai Instrumental dan nilai Praksis yang berpangkal tolak pada nilai Fundamental Kertamasa yaitu nilai-nilai tentang makna masa 
kreatif, masa kemajuan, masa kemakmuran dan masa keunggugulan dalam masa kehidupan yang aman tertib, harmonis, dan seimbang antara lahir dan bhatin. Menjadikan nilai Fundamental Kertamasa sebagai nilai dasar dari perwujudan kebijakan dan pelaksanaan dari privatisasi BUMN berarti telah melihat hukum dalam hal ini privatisasi BUMN sebagai suatu keutuhan yang merupakan sebuah tatanan (order) yang mencakup tatanan transedental (transcendental order), tatanan sosial ( social order) dan tatanan politik (political order) (Sudjito, 2012). Privatisasi BUMN bukan hanya menjadi political order karena merupakan keputusan yang dibuat oleh lembaga-politik seperti Undang Undang, Peraturan Pemerintah, Keputusan Presiden, maupun Keputusan Menteri, privatisasi mengandung transcendental order dan social order. Perwujudan Kertamasa dalam Privatisasi BUMN yang berbentuk nilai instrumental dan nilai praksis dari nila fundamental masa kreatif, masa kemajuan, masa kemakmuran dan masa keunggugulan dalam masa kehidupan yang aman tertib, harmonis, dan seimbang antara lahir dan bhatin adalah dapat diuraikan sebagai berikut;

1. Privatisasi BUMN tidak dilakukan terhadap BUMN yang bidang usahanya menguasai hajat hidup orang banyak masyarakat Indonesia, maksud dari perwujudan ini adalah penjabaran nilai fundamental kemakmuran, kesejahtaraan dan keseimbangan lahir bhatin dari Kertamasa. Negara melalui BUMNnya menjamin kepastian terpenuhinya kebutuhan hidup yang mendasar masyarakat Indonesia seperti Pertamina, PLN. Dengan adanya jaminan dari negara dalam masyarakat tidak akan terjadi kecemasan akibat gejolak semisal kenaikan harga karena dengan privatisasi BUMN harga akan ditentuan sesuai mekanisme pasar. 2. Privatisasi tidak dilakukan terhadap BUMN yang bidang usahanya berkaitan secara langsung atau tidak langsung dengan sistem pertahanan dan kedaulatan negara, maksud dari perwujudan ini adalah penjabaran nilai fundamental keamanan dan ketertiban dari Kertamasa. Penjualan BUMN seperti yang berkaitan dengan sistem pertahanan dan keamanan seperti usaha bidang persenjataan, telekomonikasi, pengelola pelabuhan udara pelabuhan laut akan berdampak pada keamanan dan kedaulatan negara yang berpotensi menganggu keamananan dan ketertiban.

3. Privatisasi tidak dilakukan terhadap BUMN yang bergerak dibidang usaha sumber daya alam, maksud dari perwujudan ini adalah penjabaran nilai fundamental keharmonisan dan keseimbangan skala-niskala manusia dengan lingkungan dari Kertamasa. Privatisasi akan mendorong perusahaan untuk mendapatkan keuntungan yang sebanyak banyaknya bahkan dengan mengabaikan kelestarian alam dan lingkungan. BUMN yang bergerak dibidang usaha sumberdaya alam mempunyai potensi yang lebih besar unntuk mengekspoitasi sumber daya alam dan lingkungan untuk mengejar keuntungan. Dengan adanya larangan privatiasi 
terhadap BUMN yang bergerak dibidang usaha sumber daya manusia maka dapat mencegah atau meminimalisir kerusakan lingkungan dengan alasan keuntungan ekonomi.

4. Privatisasi BUMN dilakukan dengan partisipasi masyarakat Indonesia secara luas, maksud dari perwujudan ini adalah penjabaran nilai kreatif, kemajuan dan kesejahtraan dari Kertamasa. Melibatkan partisipasi rakyat secara luas dapat dilakukan kepemilikan saham BUMN dan kemitraan strategis BUMN dengan UMKM dan Koperasi. Kepemilikan saham BUMN maksudnya masyarakat yang ingin membeli saham BUMN jangan dibatasi dengan pembilan minimum dengan nilai yang harganya tinggi menurut ukuran masyarakat, semisal batasan minimal membeli saham BUMN yang di privatisasi dengan kisaran harga 500 juta. Dengan penetapan harga senilai itu untuk pembilan minimal seperti itu hanya akan membuat masyarakat Indonsia dari golongan tertentu saja yang ikut berpartisipasi dalam privatisasi sehingga manfaat privatisasi BUMN hanya dapat dinikmati segelintir masyarakat, hal ini tidak akan mendorong masyarakat indonesia secara keseluruhan untuk maju dan kreatif dalam kegiatan investasi dan sekaligus dapat membatasi atau menyeimbangkan kepemilikan asing dengan kepemilikan masyarakatinonesia atas saham saham BUMN. Semakin banyak masyarakat indonesia yang memiliki saham BUMN maka semakin banyak yang mendapatkan manfaat ekonomi untuk tercapainya kemakmuran dan kesejahtraan. Smentara Itu kemitraan strategis dengan UMKN dan Koperasi adalah sebagai upaya untuk menguatkan akses UMKM dan Koperasi terhadap efektivitas usaha maupun penguatan modal. Kemitraan strategis ini akan berdampak pada peningkatan dan penyerapan tenaga kerja sehingga dapat mengurangi pengangguran.

5. Dalam kaitan dengan teknis pelaksanaan, privatisasi BUMN selayaknya dilakukan tidak berdekatan dengan perlehatan politik seperti pemilihan umum legeslatif dan pemilihan presiden, maksud dari perwujudan adalah penjabaran nilai masa/waktu untuk menciptakan keharmonisan dari Kertamasa. Pemilihan waktu privatiasi BUMN yang tidak berdekatan dengan penyelenggaran pemilihan umum untuk mencegah politisasi privatisasi BUMN. Politisasi privatisasi BUMN yang kerap terjadi selama ini berdampak pada pelaksanaan privatisasi menjadi kontradiksi yang menimbulkan suasana ketidak harmonisan yang dapat berimplikasi pada nilai kekonomisan BUMN itu sendiri yang pada ujungnya merugikan kepemilikan dari negara.

Nilai-nilai instrumen dan praksis yang bersumber pada nilai fundamental Kertamasa sangat relevan untuk dikaitkan dengan privatiasi BUMN sebagaimana yang diatur UU BUMN. Dalam Pasal 77 UUBUMN diatur tentang BUMN yang tidak dapat dilakukan privatisasi yaitu;

1. Persero yang bidang usahanya berdasarkan ketentuan peraturan-perundang hanya boleh dikelola BUMN; 
2. Persero yang bergerak di sektor usaha yang berkaitan dengan pertahanan dan keamanan negara;

3. Persero yang bergerak di sektor tertentu yang oleh pemerintah diberikan tugas khusus untuk melaksanakan kegiatan tertentu yang berkaitan dengan kepentingan masyarakat;

4. $\quad$ Persero yang bergerak dibidang usaha sumber daya alam yang secara tegas berdasarkan ketentuan peraturan perundang-undangan yang berlaku dilarang untuk diprivatiasi.

Ketentuan Pasal 77 UU BUMN ini menurut penulis belum mencerminkan nilai-nilai instrumental dan praksis yang bersumber dari nilai fundamental Kertamasa. Ketentuan dalam pasal ini masih sangat umum dengan memberikan batasan terhadap BUMN yang dilarang untuk di privatiasi mengaju pada peraturan perundang undangan lainnya dan didasarkan pada penugasan khusus oleh pemerintah. Ketentuan yang masih bersifat umum ini dapat ditafsirkan sebagai syarat dan ketentuan yang longgar dan memberikan kesan ketidak jelasan arah kebijakan dari privatisasi BUMN. Apabila kemudian disepakati untuk mentransformasi Kertamasa dalam privatisasi BUMN maka perlu dilakukan perubahan atau revisi terhadap UU BUMN khususnya ketentuan tentang privatiasi dengan tujuan untuk kesejahtraan semesta.

\section{Simpulan}

Berdasarkan analisis terhadap rumusan masalah yang telah diuaraikan dalam tulisan ini maka dapat ditarik kesimpulan sebagai berikut;

1. Kertamasa yang merupakan kerifan lokal organisasi subak di Bali dapat ditransformasi dalam privatisasi BUMN. Nilai-nilai Kertamasa yang ditransformasi dalam privatisasi BUMN adalah nilai-nilai yang bersifat fundamental yang meliputi masa kreatif, kemajuan, kemakmuran, keunggulan, keamanan, ketertiban, harmonis seimbang antara lahir dan bhatin. Nilai nilai fundamental dari Kertamasa menjadi nilai dasar untuk penjabaran nilai-nilai intrsumen dan nilai praksis dalam privatisasi BUMN.

2. Transformasi Kertamasa dalam privatisasi BUMN berwujud nilai instrumental dan nilai praksis yang bersumber pada nilai fundamental Kertamasa. Nilai instrumental dan nilai praksis belum tercermin dalam ketentuan privatisasi yang diatur dalam UU BUMN, untuk itu perlu dilakukan perubahan terhadap ketentuan privatisasi dalam UU BUMN.

\section{Daftar Pustaka}

Efendi, Faisal, Pasandaran, Effendi, dan Achmad M. Fagi, 2003," Kearifan Lokal Subak dan Kertamasa atau Pranata Mangsa "Dalam Subak dan Kerta Masa,Kearifan Lokal mendukung Pertanian Berkelanjutan, Yayasan Padi Indonesia, Jakarta

Essensi Harfiah Makna Kerta Masa, Available at http ://www.disbud.baliprov.go.id/id /2014/5/17, accessed at 4 oktober 2014.

Ilmar, Aminudin, 2012, Hak Menguasai Negara Dalam Privatisasi BUMN, Kencana Prenada Media Group, Jakarta. 
Instruksi Presiden Nomor 5 Tahun 1989.

Kailan, 2013, Negara Kebangsaan Pancasila, kultural, historis, filosofis,yuridis , dan aktualisasinya, Paradigma, Yogyakarta

Lomba Privatisasi BUMN, Siapa Menang?, Available at http://liputanislam.com/opini/, 2014/09/4, accessed at 3 oktober2014.

Peraturan Pemerintah Nomor 55 Tahun 1990 tentang Perusahaan Persero yang menjual sahamnya kepada masyarakat melalui pasar modal.

Privatisasi BUMN belum berdampak pada kesejahtraan rakyat, Available at http://www.ugm.ac.id/berita/2010/5/ 3 access at 3 oktober 2014.

Privatisasi kembali kontroversi,Available at

http://sunarsip.com/index/2011/02/2

7/, accessed at 2 oktober 2014.

Properti Negara: Kontroversi Jual Indosat dan Telkom, Available at http://jakarta45.wordpress.com/2014 /01/06/, accessed at 2 oktober 2014.

Rahardjo, Satjipto, 2003, Sisi-Sisi Lain dari Hukum Di Indonesia ,Kompas, Jakarta.

Redwood, John, 1989, Popular Capitali, 1989, Routletge, London.

Rudy Prasetya, 2001, Kedudukan Mandiri Perseroan Terbatas, Citya Aditya Bakti, Bandung.

Sejarah BUMN, IMF-World Bank dan Privatisasi Indonesia, Available at http://nusantaranews.wordpress.com /2009/06 access at 1 oktober 2014

Suarka, I Nyoman, 2014,” Dasar Sastra dan Filosofi Kretamasa dan Masa Kerta Dalam Pertanian di Bali”, Makalah dalam Sarasehan Pesta Kesenian Bali ke 36 tahun 2014, Denpasar Tanggal 3 juli.
Sudjito, 2012 , Negara Hukum Dalam

Perspektif Pancasila, Dalam Hukum Dalam Pelangi

Kehidupan, Gadjah Mada University Press, Yogyakarta.

, 2012, Tinjuan YuridisKonstitusional Konsistensi Nilai-Nilai PAncasila Dalam UUD 1945 dan Implementasinya,Gadjah Mada University Press, Yogyakarta.

Suyanto, Bagong, 2013, Sosiologi Ekonomi kapitalisme dan Konsumsi di Era Masyarakat Post Modernisme, Kencana ,Prenada Media Group, Jakarta.

Tisa Belasuriya,1993, Rapid

Privatization of The Economy, Brettonwood, USA,

Undang-Undang Dasar Negara Republik Indonesia Tahun 1945.

Undang-Undang No 19 Tahun 2003 Tentang Badan Usaha Milik Negara.

Undang-Undang No 40 Tahun 2007 Tentang Perseroan Terbatas.

UUBUMN Semakin Perlonggar Rambu-Rambu Privatisasi, Available at http://hukumonline.com/berita/b aca $/ 2003 / 06 / 02 /$, accessed at 2 oktober 2014.

Winarno, Budi, 2013, Etika Pembangunan,CAPS, Jakarta.

Windia, Wayan, 2014, Menghilangnya Tradisi Kertamasa dan Dampak Sistemik Terhadap Subak", Makalah Dalam Serasehan Pesta Kesenian Bali ke 36 Tahun 2014, Tanggal 3 Juli. 